
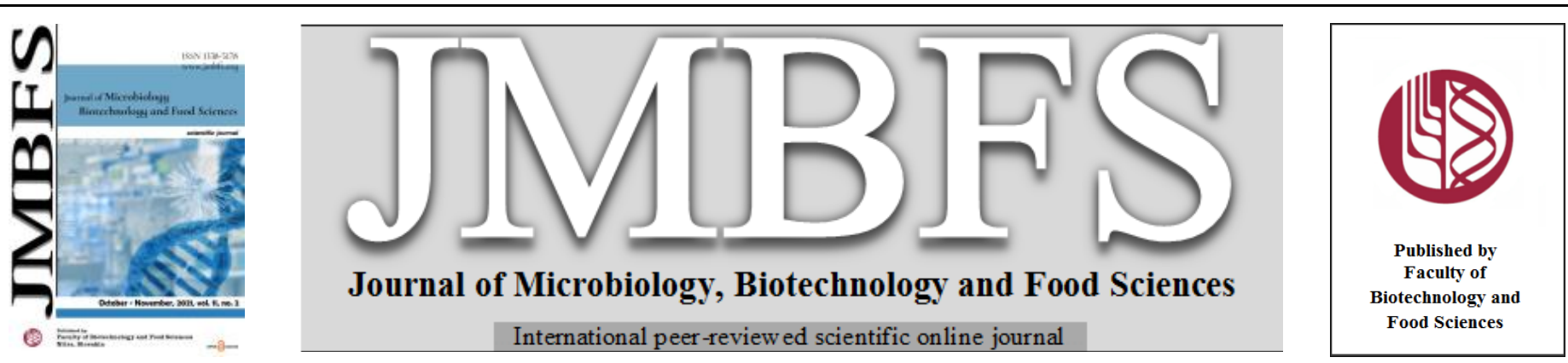

\title{
LYOPHILIZED AQUEOUS EXTRACT OF PINUS HALEPENSIS (MILL.) RESIN: CHEMICAL COMPOSITION, ANTIOXIDANT AND ANTIDERMATOPHYTIC ACTIVITIES
}

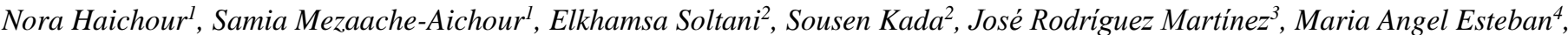 \\ Jane Nicklin ${ }^{5}$ and Mohamed Mihoub Zerroug $* 1$
}

Address(es):

${ }^{1}$ Laboratoire de Microbiologie Appliquée, Faculté des Sciences de la Nature et de la Vie, Université Ferhat Abbas Sétif 1, 19137 Sétif, Algérie. Tel. $21336620140 /$ 213774065878

${ }^{2}$ Laboratoire de Biochimie Appliquée, Faculté des Sciences de la Nature et de la Vie, Université Ferhat Abbas Sétif 1, 19137 Sétif, Algérie.

${ }^{3}$ Chief of Section Scientific Instrumentation Service (SUIC), Espinardo Campus, University of Murcia, 30100 Espinardo. Murcia, Spain.

${ }^{4}$ Fish Innate Immune System Group, Department of Cell Biology and Histology, Faculty of Biology, Regional Campus of International Excellence "Campus Mare Nostrum", University of Murcia, 30100 Murcia, Spain..

${ }^{5}$ Department of Biological Sciences, Institute of Structural and Molecular Biology, School of Biological and Chemical Sciences, Birkbeck College, University of London, Malet Street, London WC1E 7HX,UK.

*Corresponding author: med.zerroug@univ-setif.dz

https://doi.org/10.15414/jmbfs.3423

\section{ARTICLE INFO}

Received 10. 7. 2020

Revised 18. 5. 2021

Accepted 18. 5. 2021

Published 1. 10. 2021

Regular article OPEN $\partial_{\text {ACCESS }}$

\begin{abstract}
In traditional Algerian medicine, Pinus halepensis (Mill.) resin is used as antimicrobial, anti-inflammatory, analgesic, wound healer, for the treatment of respiratory and urinary diseases. In the present study, a lyophilized aqueous extract (LAE) of Pinus halepensis (Mill.) resin is subjected to chemical composition analysis by gas chromatography coupled to mass spectrometry (GC/MS), antioxidant activity was evaluated in vitro using 2,2-diphenyl-b,picrylhydrazyl (DPPH) and $\beta$-carotene bleaching assays. LAE of Pinus halepensis (Mill.) resin was also tested for its potential activity against four dermatophytic fungi: Trichophyton rubrum, Trichophyton equinum, Trichophyton mentagrophytes, Trichophyton tonsurans. Results showed that LAE of Pinus halepensis (Mill.) resin contained 64.57\% of aromatic compounds. This extract contains also succinic acid, sugars and alcohol sugars, alkaloids and other compounds that represent respectively $0.58 \%, 6.45 \%, 0.87 \%$ and $2.05 \%$. The obtained extract exhibited satisfying antioxidant activity with an inhibition percentage of $93.76 \pm 0.41$ at a concentration of $300 \mu \mathrm{g} / \mathrm{mL}$ and $\mathrm{IC}_{50}$ of $83.64 \mu \mathrm{g} / \mathrm{mL}$ by the DPPH method. The tested extract showed also a good antioxidant activity using $\beta$-carotene test. At resin concentration of $100 \mu \mathrm{g} / \mathrm{mL}$ antifungal tests showed, inhibition rates of $58.9 \%, 58.44 \%, 41.36 \%$ and $34.43 \%$ against $T$. tonsurans, T. equinum, T. rubrum and T. mentagrophytes respectively. Upon the obtained results, this extract can be used as external treatments for wounds to prevent oxidation and fungal infections.
\end{abstract}

Keywords: Pinus halepensis, resin, GC/MS, antioxidant activity, antifungal activity

\section{INTRODUCTION}

Plants have been used as an important source of medicine since ancient times and their products are being used for different purposes such as medicine, food, health care, agriculture, agrochemicals, pharmaceutical, etc. The medicinal properties of different plant species have contributed to the origin and evolution of many traditional herbal therapies (Malik et al., 2012). The importance of medicinal plants lies in their biological active principles, which are the real healers in the process of medication (Kumar, 2009).

The Aleppo pine or Pinus halepensisis (Mill.) is a tree species of primary importance in the Mediterranean by the area it occupies and the role it plays in the economy of countries in this region (Nahal, 1962). The resins are considered to play a role in the defence of the coniferous trees against insects and microbial pathogens (Trapp and Croteau, 2001). Natural coniferous resins extracts are raw materials for various products in the industry and have been used as traditional medicines as a homemade salve for skin wounds and infections (Sipponen, 2013). Natural resins have a very wide range of applications, mainly used in industries coatings (varnishes, lacquers, paints, sealants, cements, adhesives...), printing (printing inks...), stationery (paper sizing), polymers (adhesives, rubber, various materials). Gums and many resins are also the sources of varied products for the food industry, perfumery, cosmetics, pharmacy and medicine (Delmond, 2002; Ghanmi et al., 2007).

Several medical traditionally uses of $P$. halepensis (Mill.) were recorded in Algeria according to regions and diseases. Different parts of pine were used in decoction; infusion, pine resin powder mixed with honey or olive oil (Meddour and Meddour-Sahar, 2015). Fruits infusion for the treatment of arterial hypertension (Sarri et al., 2012), buds, leaves and resin decoction and poultice for the treatment of respiratory and urinary tract disorders, antiseptic and stimulant of adrenalglands (Benderradji et al., 2014), fruits infusion and powder for haemorrhoids, tuberculosis, ulcer treatments and pulmonary conditions (Sarri et al., 2015). Seeds decoction for the treatment of gastric and intestinal ulcers, respiratory infections, prostate infection, sterility, toothache (Bouasla and Bouasla, 2017), stomachache and kidney inflammation (Senouci et al., 2019). Roots decoction for the treatment of respiratory disorders (Chohra and Ferchichi, 2019). The resin was used against rheumatism (Rebbas et al., 2012), to treat asthma (Meddour and Meddour-Sahar, 2015), as antifungal (Chermat and Gharzouli, 2015) and to treat mainly burns, wounds and skin inflammation, in flu and cough cases (Meddour and Meddour-Sahar, 2015). Leaves, resin infusion and decoction for the treatment of respiratory ailments (bronchitis, pneumonia and colds), urinary problems, parasitosis and wounds (Miara et al., 2019; Bendif et al., 2020).

Several studies reported that the most important fungal species implied in dermatophytic diseases in Algeria belonged to Tricophyton genus. They were predominant in the Northeast, $66.68 \%$ including Trichophyton rubrum and Trichophyton tonsurans (Hammadi et al., 2007). Trichophyton rubrum was the predominant pathogen of feet and the inguinal folds in Sétif (Ilham and Touabti, 2013), Trichophyton mentagrophytes primarily responsible for the inflammatory disease in Batna (Chelgham et al., 2012). While in 2016 , Ennaghra et al. found that the occurrence of trichophytic was $72 \%$ among this percentage there were $24 \%$ T. rubrum and $16 \%$ T. mentagrophytes.

In the last decade most research done on pine in Algeria were focused on the organic solvent extraction of essential oils from aerial parts of the tree, spines (Abi-Ayad et al., 2011), needles (Fekih et al., 2014; Dob et al., 2005), twigs and buds (Fekih et al., 2014), flowering aerial parts (Haichour et al., 2020) or pine 
extracts, leave and bud decoction (Berroukche $\boldsymbol{e t}$ al., 2014), bark aqueous extract (Kaouachi and Derouiche, 2018), young ovulate cones methanolic extract (Meziti et al., 2019) and seeds polysaccharides (Abbou et al., 2019). On the bases of the available literature about the extracts and the ethnobotanical use of Pinus halepensis (Mill.) and the biological activities focused on antioxidant and antifungal especially phytopathogenic fungi (El Omari et al., 2021), the extract and the use of pine resin aqueous extract seem to be more close to the folk use of pine. Thus the aim of this work, which is in our knowledge the first study done in Algeria, was to determine the chemical composition as well as the antioxidant and antifungal activities of a lyophilized aqueous extract of Pinus halepensis (Mill.) resin collected in Sétif region (Northeast of Algeria).

\section{MATERIAL AND METHODS}

Preparation of lyophilized aqueous extract (LAE) of Pinus halepensis (Mill.) resin

Resin samples are collected in the north of Sétif region (in the Northeast of Algeria). A sample of $1.9 \mathrm{~g}$ of air-dried resin is ground into a fine powder in a blender and mixed with $90 \mathrm{~mL}$ boiling water by a magnetic stirrer for $4 \mathrm{~h}$. The aqueous extract was then filtered over cheesecloth and Whatman paper No. 1, respectively. The filtrates were frozen at $-20^{\circ} \mathrm{C}$ in ultra-low temperature freezer and lyophilized in a dry freezer machine (Cryorivoire) under 260-mTorr pressure at $-81^{\circ} \mathrm{C}$ (Gülçin et al., 2007).

\section{Chemical composition of LAE of Pinus halepensis (Mill.) resin by GC / MS}

The identification of the components of LAE of $P$. halepensis resin was performed based on the gas chromatography coupled to mass spectrometry (GC / MS) as described by Mansouri et al. (2011) and Soltani et al. (2017). Five (5) $\mathrm{mg}$ of pine resin samples of LAE were mixed with $50 \mu \mathrm{l}$ of dry pyridine and $75 \mu \mathrm{L}$ N,O-bis (trimethylsilyl) trifluoracetamide, heated at $80^{\circ} \mathrm{C}$ for $20 \mathrm{~min}$ and analyzed by GC-MS. This technique is performed using a Hewlett Packard Gas Chromatograph 6890 Series II Plus linked to Hewlett Packard 6972 mass spectrometer system equipped with capillary column HP5-MS (30 m long, 0.25 $\mathrm{mm}$ id and $0.5 \mu \mathrm{m}$ film thicknesses). The column temperature is programmed from 100 to $325^{\circ} \mathrm{C}$ at a rate of $5^{\circ} \mathrm{C} / \mathrm{min}$. The carrier gas is helium with a flow rate set at $20 \mathrm{~mL} / \mathrm{min}$. The injection mode is Split (Split ratio 50:1, injector temperature $280^{\circ} \mathrm{C}$ ). The identification of the compounds present in pine resin LAE samples is accomplished using computer searches on commercial libraries. In some cases, when identical spectra have not been found, only the structural type of the corresponding component was proposed based on its mass-spectral fragmentation. If available, reference compounds were co-chromatographed to confirm GC retention times. Components identification is verified by search in NIST Data Base using CAS numbers (http://webbook.nist.gov/chemistry/).

\section{Antioxidant activity}

\section{Radical scavenging by DPPH method}

Antioxidant activity of pine resin LAE is evaluated according to the DPPH $(1,1$ diphényl-di-picrylhydrazyl) method proposed by Chen $\boldsymbol{e t} \boldsymbol{a l}$. (2004) and Que $\boldsymbol{e}$ al. (2006). Two (2) $\mathrm{mL}$ of LAE of P. halepensis (Mill.) resin solution $(2 \mathrm{mg} / \mathrm{mL}$ ) and different concentrations of BHT (butylated hydroxytoluene) in distilled water are mixed with $2 \mathrm{~mL}$ of $0.1 \mathrm{mM}$ DPPH solution in methanol. Control is prepare with the same method but the tested substance is substituted by distilled water. After $30 \mathrm{~min}$ in dark, DPPH discoloration is measured at $517 \mathrm{~nm}$ with a spectrophotometer (thermo- Sientific: HEরIOS ${ }^{\circ} 490$ ) using distilled water as blank. All tests are performed in triplicate. Extracts scavenger activity in \% is calculated according to the following formula: scavenger activity in $\%=[(\mathrm{Ac}-$ $\mathrm{Ae}) / \mathrm{Ac}] \mathrm{x} 100$ where:

$\mathrm{Ac}=($ Absorbance of control $), \mathrm{Ae}=($ Absorbance of tested extract $)$

The graph of the inhibition percentage variation as a function of tested extract concentrations allows determining the $\mathrm{IC}_{50}$, concentration corresponding to $50 \%$ inhibition of DPPH radicals. This value is compared to that recorded for the reference compound (BHT)

\section{$\beta$-carotene bleaching test}

The antioxidant capacity is determined by measuring inhibition of volatile organic compounds production and the formation of conjugated dienehydroperoxides arising from linoleic acid oxidation which results in the discoloration of $\beta$-carotene (Krishnaiah et al., 2011). $\beta$-carotene bleaching test is realized according to the method described by Sun and Ho (2005). In a flask, $1 \mathrm{ml}$ of $\beta$-Carotene solution ( $1 \mathrm{mg} / \mathrm{mL}$ of pure chloroform) is added to $25 \mu \mathrm{L}$ of linoleic acid and $200 \mathrm{mg}$ of the Tween 40 emulsifier mixture. After evaporation of the chloroform by rotary evaporator (Rotamantle) at $42^{\circ} \mathrm{C}, 100 \mathrm{~mL}$ of oxygensaturated distilled water are added with vigorous shaking until emulsification.
Next, $10 \mathrm{ml}$ of this mixture are transferred into test tubes containing $2 \mathrm{~mL}$ of distilled water (control), $2 \mathrm{~mL}$ of BHT solution (positive control, standard antioxidant) at $2 \mathrm{mg} / \mathrm{mL}$ of methanol or $2 \mathrm{~mL}$ of different concentrations of the tested extract; all tests are performed in triplicate. As soon as the emulsion is added to each tube, the zero time point absorbance is measured at $490 \mathrm{~nm}$ by a spectrophotometer (thermo- Sientific: HE IOS $^{\circ} 490$ ), blank contains all emulsion components but devoid of $\beta$-carotene. After incubating emulsion for $2 \mathrm{~h}$ at $50^{\circ} \mathrm{C}$, absorbance readings are taken at regular intervals $(15 \mathrm{~min})$ until $2 \mathrm{~h}$ (decolorized $\beta$-carotene)

\section{Antifungal activity of resin LAE of P.halepensis (Mill.) resin}

The LAE of Pinus halepensis (Mill.) resin was tested in plate based poisoned bait assays against four dermatophytic fungi Trichophyton rubrum, Trichophyton equinum, Trichophyton mentagrophytes and Trichophyton tonsurans obtained from the laboratory of Dr. Jane Nicklin, School of Biological and Chemical Sciences, Birkbeck College, University of London, UK.

The dermatophytic fungi are cultivated on Sabouraud dextrose agar (Oxoid LTD, Basing Stoke, Hampshire, England). Resin LAE dissolved in methanol is added to the medium at the concentrations of $12.5 \mu \mathrm{g} / \mathrm{mL}, 25 \mu \mathrm{g} / \mathrm{mL}, 50 \mu \mathrm{g} / \mathrm{mL}$ and $100 \mu \mathrm{g} / \mathrm{mL}$. The medium containing the appropriate concentration of $\mathrm{MeOH}$ without pine resin extract is used as control. Plates are incubated at $25^{\circ} \mathrm{C}$ for 9 days. The fungal growth inhibition rates are calculated according to the equation: Inhibition $\%=[(\mathrm{Cd}-\mathrm{Td}) / \mathrm{Cd})] \times 100$ where $\mathrm{Cd}$ : control colony diameter, Td: test colony diameter. Results converted to prohibit values (Finney, 1971), are plotted against the $\log 2$ of the dilution factor in order to determine the dilution required to inhibit germination by $50 \%$.

\section{Statistical analysis}

Results are expressed as mean \pm SD. Graphs were realized by Graph Pad Prism 8.4.2 Statistical software (Graph Pad Software, USA). Statistical significance of the difference was assessed by a two-way analysis of variance. Differences were considered significant at $\mathrm{p}<0.05$.

\section{RESULTS AND DISCUSSION}

\section{Chemical composition of resin LAE of P.halepensis (Mill.)}

Analysis of the chemical composition of the LAE of pine resin by GC/MS resulted in the identification of 53 compounds. The most representative results according to the NIST database (Table 1), are aromatic compounds such as cinnamic and benzoic acids derivatives that represent, quantitatively the most important fraction. Among phenolic compounds, cafeic acid area is $35.52 \%$. Methyl ester of salicylic acid, 3,5-Bis (1,1-dimethylethyl) catechol, vanillin, [1,1'-biphenyl]-4,4'-diol, 3,3'-dimethoxy-, isoferulic acid, coumarin 3-(1,1dimethylallyl)-7-hydroxy-6-methoxy-), $p$-salicylic acid (4-hydroxybenzoic acid) protocatechuic acid and even thymol are respectively present at percentages of $5.53,5.09,3.84,3.05,2.73,1.80,1.78,0.97$ and 0.63 . Besides, the analysis reveals the presence of a variety of sugars representing $6.45 \%$. This aqueous extract also contains succinic and phosphoric acids, D-verbenone and alkaloids as tetra hydroharmane. Total percentage area of identified compounds, referring to the NIST database, is $74.52 \%$.

Natural resins are complex mixtures of several classes of compounds, the main ones as described by Delmond (2002) are in addition to essential oils and polysachrides, acid constituents, aliphatic as succinic acid, aromatic as benzoic and cinnamic acids and phenolic acids as salicylic, $p$-coumaric and ferulic acids combined as esters to resin alcohols (resinols and resinotannols) and phenolic compounds as urushiol. Natural resins contain also neutral constituents, essentially triterpenic in the majority (Ghanmi et al., 2007), resin alcohols, free or as esters and are generally phenolic. The compounds present in greater quantities in the Pinus genus are mono or sesquiterpenes (Ghanmi et al., 2007, Simard, 2007; Abi-Ayad et al., 2011), their concentrations vary with species. Several diterpenes were isolated from different parts of pines (Simard, 2007) Earlier Karepova et al. (1983) reported that the aqueous extract of the woody verdure of Pinus sylvestris contained aliphatic mono-, di- and tricarboxylic acids and benzene carboxylic acids. Among aromatic acids, they found benzoic acid in the largest amounts. These results are consistent with the obtained results, Pinus halepensis (Mill.) resin LAE also contained aliphatic acids such as succinic acid and a significant amount of aromatic compounds such as benzoic and cinnamic acids derivatives greatly represented by cafeic acid. Sugars are present at $6.45 \%$; these sugars derived probably from the hydrolysis of polysaccharides following sample boiling. This is reinforced by data of Sipponen (2013), who found constantly coumaric acid (hydroxycinnamic acid), a group of resin acids (hydroxyabietic and abietic acids) and a group of lignans specially pinoresinolin natural coniferous resins and other terpenic wood extracts. 
Table 1 Components of Pinus halepensis (Mill.) resin lyophilized aqueous extract identified by GC/MS

\begin{tabular}{|c|c|c|c|}
\hline & Compounds & $\%$ area & $\begin{array}{c}\text { Total \% } \\
\text { area }\end{array}$ \\
\hline $\begin{array}{l}\text { Linear hydrocarbon } \\
\text { acids }\end{array}$ & succinic acid & 0.58 & 0.58 \\
\hline \multirow{15}{*}{$\begin{array}{l}\text { Aromatic compounds } \\
\text { and derivatives }\end{array}$} & 2,6-Difluoroaniline or 2,6-difluoro Benzenamine & 0.58 & \multirow{15}{*}{64.57} \\
\hline & Vanillin & 3.84 & \\
\hline & 3',5'-Bis(trifluoromethyl) acetophenone & 0.3 & \\
\hline & 4-Hydroxybenzoic acid $p$-Salicylic acid & 1.78 & \\
\hline & vanillic acid & 1.00 & \\
\hline & Protocatechuic acid & 0.97 & \\
\hline & Coumarin, 3-(1,1-dimethylallyl)-7-hydroxy-6-methoxy-) & 1.80 & \\
\hline & Isoferulic acid & 2.73 & \\
\hline & Caffeic acid & 35.52 & \\
\hline & [1,1'-Biphenyl]-4,4'-diol, 3,3'-dimethoxy- (or 4,4'-Biphenyldiol, 3,3'-dimethoxy-) & 3.05 & \\
\hline & 3-Methyl-2-phenylindole ( 3-Methyl-2-phenylindole & 0.72 & \\
\hline & Thymol & 0.63 & \\
\hline & M-methoxymandelic acid oumethyl ester of salicylic acid & 5.53 & \\
\hline & 2-(1H-benzimidazol-2-yl) aniline & 1.03 & \\
\hline & 3,5-Bis(1,1-dimethylethyl) catechol & 5.09 & \\
\hline \multirow{4}{*}{$\begin{array}{l}\text { Sugars and their } \\
\text { alcohols }\end{array}$} & Arabinose & 2.69 & \multirow{4}{*}{6.45} \\
\hline & Xylitol & 0.97 & \\
\hline & D-Xylopyranose & 0.59 & \\
\hline & D-Glucose & 2.20 & \\
\hline Alkaloids & Tetrahydroharmane & 0.87 & 0.87 \\
\hline \multirow{3}{*}{ Others } & Phosphoric acid & 0.69 & \multirow{3}{*}{2.05} \\
\hline & D-Verbenone or 2-Pinen-4-one & 0.49 & \\
\hline & ether of glycerol & 0.87 & \\
\hline
\end{tabular}

\section{Antioxidant activity}

Plants rich in flavonoids and phenolic acids are a good source of natural antioxidants. A positive and significant correlation existed between antioxidant activity and total phenolics (Wojdylo et al., 2007; Ignat et al., 2011). The pine bark provide a readily available source of dietary antioxidants (Walia et al. 2019).

\section{DPPH test}

The test results of the free radicals scavenging effect from the LAE of pine resin and BHT (Fig. 1) demonstrate a fairly significant capacity for trapping the DPPH radical and are concentration-dependant. Maximum inhibition $(93.76 \% \pm 0.41)$ was recorded at $300 \mu \mathrm{g} / \mathrm{mL}$; however, at $200 \mu \mathrm{g} / \mathrm{ml}$ inhibition is already almost in a maximum of $92.23 \% \pm 0.13$. According to the results, the $\mathrm{IC}_{50}$ as determined from the trend curve is $83.64 \mu \mathrm{g} / \mathrm{mL}\left(\mathrm{R}^{2}=0.9642\right)$. The positive control BHT, also shows a scavenging DPPH power with an $\mathrm{IC}_{50}$ of $45.11 \mu \mathrm{g} / \mathrm{mL}\left(\mathrm{R}^{2}=0.9324\right)$ It is also noteworthy that the inhibition rate was over $90 \%$ at only $150 \mu \mathrm{g} / \mathrm{mL}$ and $200 \mu \mathrm{g} / \mathrm{mL}$ for BHT and resin LAE respectively $(\mathrm{p}<0.05)$. The obtained $\mathrm{IC}_{50}$, was close to the $\mathrm{IC}_{50}$ obtained by Abbou et al. (2019) using of the propanol polysaccharide extract of $P$. halepensis (Mill.) seeds.

LAE pine resin contains important amounts of phenolic derivatives as cafeic, isoferulic, vanilic acids, vanillin, methyl ester of salicylic acid and $p$-salicylic acid. Indeed, García-Pérez et al. (2010) reported that polyphenolics from black spruce extract, obtained by hot water extraction is the most efficient antioxidant and showed the highest scavenging capacity among Canadian species (with $\mathrm{EC}_{50}$ $48.30 \mu \mathrm{g} / \mathrm{mL}$ and $1352.66 \mu \mathrm{g} / \mathrm{mL}$ toward $\mathrm{H}_{2} \mathrm{O}_{2}$ and $\mathrm{NO}$ respectively). The obtained aqueous pine resin extract has an $\mathrm{EC}_{50}$ lower than $83.64 \mu \mathrm{g} / \mathrm{mL}$; it has then a good scavenging activity toward DPPH radicals. García-Pérez $\boldsymbol{e t}$ al. (2010) reported that the ability of extracts to scavenge $\mathrm{H}_{2} \mathrm{O}_{2}$ is strongly associated with total phenolics, proanthocyanidins and cinnamic acids. Similarly, the ability of extracts to scavenge $\mathrm{O}_{2}{ }^{-}$was strongly correlated with total phenolics whereas the extracts ability to scavenge the $\mathrm{OH}$ radical was strongly correlated with the cinnamic acids content. These results suggest that overall antioxidant effect towards the $\mathrm{H}_{2} \mathrm{O}_{2}$ and $\mathrm{O}_{2}^{-}$could be due to the synergistic influence of different phenolic classes present in the extract. According to Bougandoura and Bendimerad (2013), the inhibition percentage of aqueous and methanolic extracts of Satureja calamintha was greater than $90 \%$ at concentrations of 4.624 and $5.0 \mathrm{mg} / \mathrm{mL}$ respectively. They also suggested that the power reducing of Satureja calamintha species is probably due to the presence of hydroxyl group in the phenolic compounds that can serve as an electron donor. Aqueous extracts are then good antioxidants, indeed LAE of $P$. halepensis (Mill.) resin shows inhibition of $92.23 \pm 0.13 \%$ at a concentration of only $200 \mu \mathrm{g} / \mathrm{mL}$.

\section{$\beta$-carotene bleaching test}

Based on the results of $\beta$-carotene bleaching assay of pine resin LAE (Fig. 2), the OD recorded at $\mathrm{T}=0 \mathrm{~min}$ is higher than those recorded for other time intervals. The decrease in OD occured between 0 and 15 minutes and then became slower for the resin and BHT. The decrease in absorbance is however very marked for the aqueous and methanolic controls devoid of resin extract following the disappearance of the $\beta$-carotene, the oxidation of linoleic acid is at a maximum after $60 \mathrm{~min}$. BHT appeared the most potent antioxidant; the LAE of $P$. halepensis resin also showed a remarkable and significant antioxidant effect by inhibiting $\beta$-carotene oxidation. Neacsu et al. (2007) isolated six knotwood flavonoids, two flavonoid glucosides and one cinnamic acid derivative from Jack pine and European aspen knotwood, all compounds inhibited lipid peroxidation and scavenge peroxyl radicals, their antioxidant properties are close to that of the reference compound Trolox. Kouamé et al. (2009) highlighted the radical scavenging activity of samples extracted from leaves richer in polyphenols and galls of Guiera senegalensis by measuring the inhibition of $\beta$-carotene oxidative degradation.

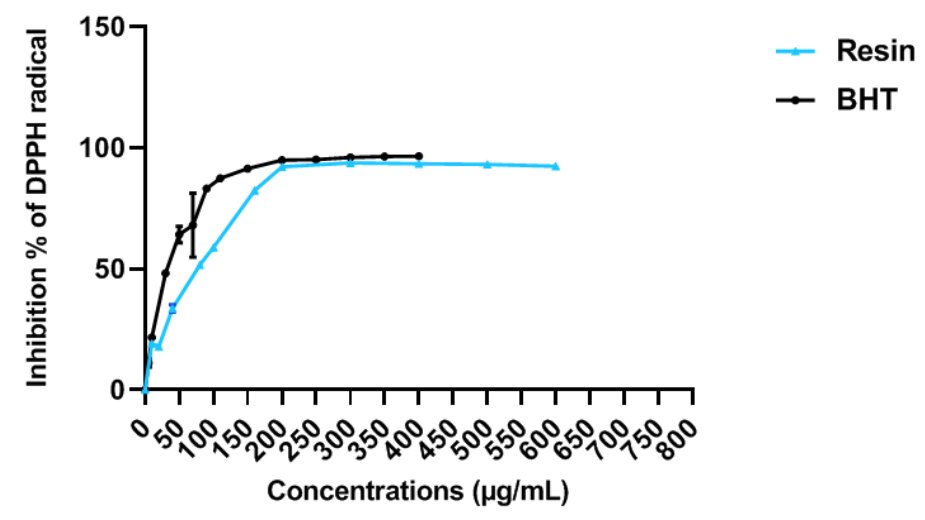

Figure 1 Scavenging effect percentage of DPPH free radicals by LAE (lyophilized aqueous extract) of Pinus halepensis (Mill.) resin and BHT (butylated hydroxytoluene; $\mathrm{p}<0.05$ ).

Pycnogenol containing organic acids- cafeic, cinnamic, fumaric, gallic, vanillic ferulic, and protacatechuic, extracted from French Maritime pine tree bark, (Simpson et al., 2019), provided photoprotection, reduce hyperpigmentation of human skin and improveed skin barrier function and extracellular matrix homeostasis (Grether-Beck et al., 2016). Several research studies have demonstrated the antioxidant potential of derivatives of the components of Pinus genus as proanthocyanidin, cinnamic acid and its derivatives. The tested LAE pine resin extract contained a relatively large fraction consisting of cinnamic acid derivatives which are more active antioxidants than those of benzoic acid derivatives (Eom et al., 2012). According to Ku et al. (2007), hot water extracts from Pinus densiflora, $P$. radiata and $P$. rigida indicated greater antioxidant activity owing to high proanthocyanidin content. The same authors also suggest that $P$. radiata bark can be considered as a natural resource for biological and pharmaceutical applications why not the LAE resin; which was also obtained by hot water extraction. The present results showed also the presence of cafeic, vanillic, isoferulic and protocatechuic acids in $P$. halepensis resin LAE obtained by hot water that can be used as a potent radical scavenger and consequently as potent antioxidant. 


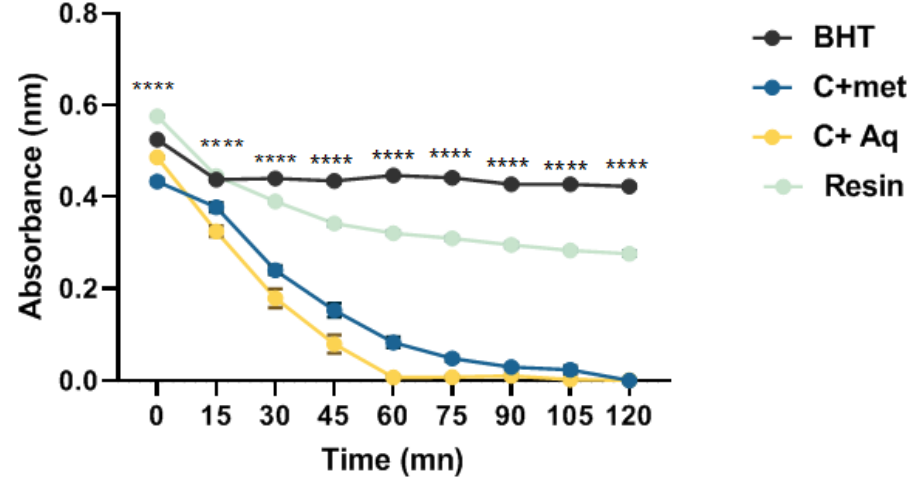

Figure 2 Antioxidant activity of Pinus halepensis (Mill.) resin lyophilized aqueous extract (resin), butylated hydroxytoluene (BHT), distilled water (c Aq) and methanol control $(\mathrm{C}$ Met) using $\beta$-carotene bleaching test $(\mathrm{p}<0.05)$.

\section{Antifungal activity of Pinus halepensis (Mill.) resin LAE}

P. halepensis (Mill.) LAE resin had different inhibitory effects on the tested fungi, depending on the fungi, the concentrations and the time of incubation. The most important effect is obtained with $100 \mu \mathrm{g} / \mathrm{mL}$. The percent inhibition was of $58.9 \% ; 58.44 \% ; 41.36 \%$ and $34.43 \%$ against $T$. tonsurans, T. equinum, $T$. rubrum and T. mentagrophytes respectively, Differences were highly significants $(* * * *$, p $<0.05$; Fig. 3). When probits were plotted against $\log _{2}$ concentration of resin LAE samples, the relation was linear and the concentration required for $50 \%$ inhibition is $77 \mu \mathrm{g} / \mathrm{mL}$ for $T$. tonsurans and $78 \mu \mathrm{g} / \mathrm{mL}$ for $T$. Rubrum and $T$ equinum. T. tonsurans was the most sensitive to the extract and $T$. mentagrophytes was the most resistant one.

The antifungal activity of the pine resin aqueous extract may be related to its chemical composition. The pine resin aqueous extract contains some compound which has antifungal activity such as caffeic acid (Chang $\boldsymbol{e t}$ al., 2011) and thymol (Falcone et al., 2005; Guo et al., 2009; de Lira Mota et al., 2012; Dias de Castro et al., 2015).

In fact, caffeic acid strongly inhibited the growth of Ganoderma boninense at a concentration of $2.5 \mathrm{mg} / \mathrm{mL}$ (Chang et al., 2011). Thymol (THY) had in vitro antifungal activity against 24 fluconazole (FLC)-resistant and 12 FLC-susceptible clinical isolates of Candida albicans (Guo et al., 2009) and against C. albicans and C. krusei with inhibitor concentrations (MIC) of $39 \mu \mathrm{g} / \mathrm{mL}$ and $78 \mu \mathrm{g} / \mathrm{mL}$ respectively (Dias de Castro et al., 2015).

According to de Oliveira Pereira et al. (2013), eugenol (contains phenolic group) inhibited Trichophyton rubrum strains with MICs from $64-512 \mu \mathrm{g} / \mathrm{mL}$. The obtained extract also contains a considerable amount of phenolic compounds which can be responsible for growth inhibition of the tested dermatophytic fungi. Using the agar plate diffusion method, Rautio et al. (2012) found that resin purified from Norway spruce (Piceaabies) in salve mixture had antifungal activity against trichophytic fungi. These authors confirm that the salve with a resin concentration of $20 \%$ or more caused a significant fungicidal effect against T. rubrum, T. mentagrophytes and T. tonsurans.

Increasingly, plant aqueous extracts are effective as significant and remarkable antifungal. Schmourlo et al. (2005) reported that lyophilized aqueous extracts of Xanthosomas agittifolium, according to popular use, inhibited the growth of $T$. rubrum strains isolated from clinical cases by an inhibition zone diameter of 18 $\mathrm{mm}$ with a lowest MIC of $100 \mathrm{ng} / \mathrm{mL}$ against $T$. rubrum.

Shams Ghahfarokhi et al. (2004) reported that AOE (aqueous onion extract), a different concentrations, inhibited significantly the growth of both T. rubrum and T. mentagrophytes in a dose- and time-dependent manner compared with the controls. It was found that the AOE had fungistatic effect from $0.78 \%$ to 3.12 $(\mathrm{v} / \mathrm{v})$ and fungicidal properties at the range of 6.25 to $50 \%(\mathrm{v} / \mathrm{v})$ for both fungi at all culture periods.

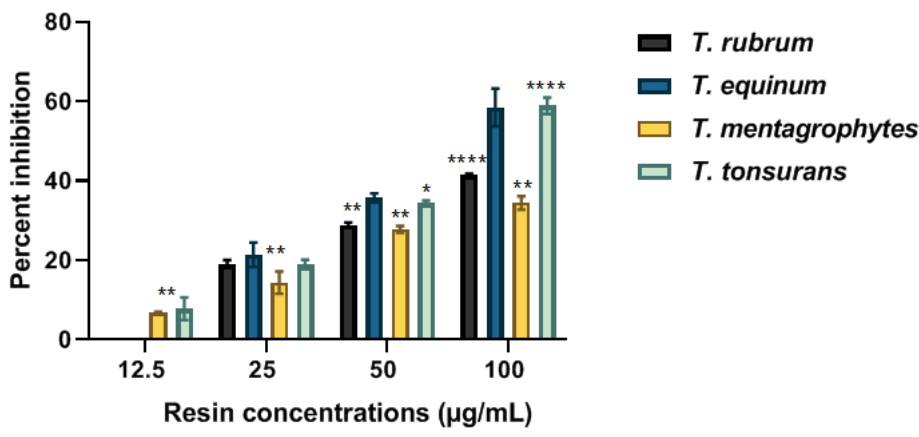

Figure 3 Growth inhibition percentages of tested dermatophytic fungi by lyophilized aqueous extract (LAE) of Pinus halepensis (Mill.) resin $(\mathrm{p}<0.05)$

\section{CONCLUSION}

The results of this study showed that Pinus halepensis (Mill.) resin lyophilized aqueous extract has considerable anti-oxidant and antifungal activities in vitro. Also, it contains important amounts of phenolic compounds and can be used as natural source of antifungal and antioxidants valuable in food supplement. It is hoped that efforts will continue to discover natural active compounds derived from plants with potent therapeutic action devoid of toxicity. We should then maintain our efforts in protecting and valorizing our natural patrimony, as well as scientific research on $P$. halepensis (Mill.) resin from chemical analysis, biological, toxicological and pharmacological investigations to therapeutic aspects.

Acknowledgments: Authors would like to thank the Ministry of Higher Education and Scientific Research of Algeria and the Directorate General for Scientific Research and Technological Development (DGRSDT) for the financial assistance. Project reference D01N01UN190120190003.

\section{REFERENCES}

Abbou, A., Kadri, N., Debbache, N., Dairi, S., Remini, H., Dahmoune, F. Berkani F., Adel, K., Belbahi, A. \& Madani, K. (2019). Effect of precipitation solvent on some biological activities of polysaccharides from Pinus halepensi Mill. seeds. International Journal of Biological Macromolecules, 141, 663-670. doi: 10.1016/i.ijbiomac.2019.08.266

Abi-Ayad, M., Abi-Ayad, F.Z., Lazzouni, H.A., Rebiahi, S.A., Ziani-Cherif, C. \& Bessiere. (2011). Chemical composition and antifungal activity of Aleppo pine essential oil. Journal of Medicinal Plants Research, 5(22), 5433-5436. https://doi.org/10.5897/JMPR.9000340

Benderradji, L., Rebbas, K., Ghadbane, M., Bounar, R., Brini, F. \& Bouzerzour, H. (2014). Ethnobotanical study of medicinal plants in Djebel Messaad region (M'SILA, ALGERIA). Global Journal of Research on Medicinal Plants \& Indigenous $\quad$ Medicine, 3(12), 445-459. https://search.proquest.com/docview/1644728445/fulltextPDF/77D7D628D1004 B7DPQ/1

Bendif, H., Soulah, N., Miara M.M., Daoud, N., Benmiri, Y., Lazli, M., Khafha H. \& Bahlouli F. (2020). Medicinal plants popularly used in the rural communities of Ben Srour (South East of M'Sila, Algeria). AgroLife Scientific Journal, 9(2), 45-55. http://agrolifejournal.usamv.ro/pdf/vol.IX_2/vol9_2.pdf Berroukche, A., Amara, S., Halimi, S. \& Benyamina, F. (2014). Evaluation of the leave and bud decoctions Pinus halepensis Mill. effects on the induced-pheno renal toxicity in Wistar rats. Journal of Fundamentals and Applied Sciences, 6(2), 197-207. http://jfas.info/psjfas/index.php/jfas/issue/view/27

Bouasla, A. \& Bouasla, I., (2017). Ethnobotanical survey of medicinal plants in northeastern of Algeria. Phytomedicine, 36, 68-81. https://doi.org/10.1016/j.phymed.2017.09.007

Bougandoura, N. \& Bendimerad, N. (2013). Evaluation de l'activité antioxydante des extraits aqueux et méthanolique de Satureja calamintha ssp. Nepeta (L.) Briq. Revue «Nature \& Technologie». B-Sciences Agronomiques et Biologiques, 9, 14-19. (Frensh) https://www.univ-chlef.dz/revuenatec/Issue 09 Art_B 03.pdf Chang, K.P., Rossal, S. \& Atong, M. (2011). HPC fingerprints and in vitro antimicrobial activity of synergic acid, caggeic acid and 4-hydrobenzoic acid against Ganodermaboninense. Journal of Applied Sciences, 11(13), 2284-2291. doi: 10.3923/jas.2011.2284.2291

Chelgham, I., Belkhelfa, S, Achachi, S., Aissaoui, I., \& Mohamdi, N. (2012). Les mycoses superficielles: à propos des cas diagnostiques dans la région des Aures (Batna)/ Algérie de 2002 à 2011. Journal de Mycologie Médicale, 22(1), 113. https://doi.org/10.1016/j.mycmed.2011.12.045

Chen, C.N., Wu, C.L. \& Lin, J.K. (2004). Propolin C from propolis induces apoptosis through activating caspases, Bid and cytochrome c release in human melanoma cells. Biochemical Pharmacology, 67, 53-66. https://doi.org/10.1016/j.bcp.2003.07.020

Chermat, S. \& Gharzouli, R. (2015). Ethnobotanical Study of Medicinal Flora in the North East of Algeria - An Empirical Knowledge in Djebel Zdimm (Setif) Journal of Materials Science and Engineering, A 5 (1-2), 50-59. doi:10.17265/2161-6213/2015.1-2.007

Chohra, D. \& Ferchichi, L. (2019). Ethnobotanical study of Belezma National Park (BNP) plants in Batna: East of Algeria. Acta Scientifica Naturalis, 6, 40-54. doi: https://doi.org/10.2478/asn-2019-0017

de Lira Mota; K.S., de Oliveira Pereira, F., de Oliveira, W.A., Oliveira Lima, I. \& de Oliveira Lima, E. (2012). Antifungal Activity of Thymus vulgaris L. Essentia Oil and Its Constituent Phytochemicals against Rhizopus oryzae: Interaction with Ergosterol. Molecules, 17, 14418-14433. doi:10.3390/molecules 171214418

Delmond, B. (2002). Résines naturelles. Techniques de l'Ingénieur, référence k340, 1-14. (Frensh)

de Oliveira Pereira, F., Mendes, J.M. \& de Oliveira Lima, E. (2013) Investigation on mechanism of antifungal activity of eugenol agains Trichophyton rubrum. Medical Mycology, 51, 507-513. doi $\underline{10.3109 / 13693786.2012 .742966}$ 
Dias de Castro, R., Murielly Pereira, T., de Souza, A., Dornelas Bezerra, L.M., Silva Ferreira, G.L., de Brito Costa, E.M.M. \& Cavalcanti, A.L. (2015). Antifungal activity and mode of action of thymol and its synergism with nystatin against Candida species involved with infections in the oral cavity: an in vitro study. BMC Complementary and Alternative Medicine, 15, 417. doi:10.1186/s12906-015-0947-2

Dob, T., Berramdane, T. \& Chelgoum, C. (2005). Chemical composition of essential oil of Pinus halepensis Miller growing in Algeria. Comptes rendus Chimie, 8, 1939-1945. https://doi.org/10.1016/..crci.2005.05.007

El Omari, N., Ezzahrae Guaouguaou, F., El Menyiy, N., Benali, T., Aanniz,T., Chamkhi, I., Balahbib, A., Taha, D., Shariati, M.A., Ghokhan, Z., El-Shazly, M \& Bouyahya, A. (2021). Phytochemical and biological activities of Pinus halepensis Mill. and their ethnomedicinal use. Journal of Ethnopharmacology, 268, 113661. https://doi.org/10.1016/j.jep.2020.113661.

Ennaghra, N., Meddour A., Soumati, B. \& Kabouchi-Bouzidi, L. (2016). Epidemiological Survey on the Dermatophyte Flora in the Area of Annaba East of Algeria. Journal of Applied Environmental and Biological Sciences, 6(12), 815. https://www.textroad.com/JAEBS-December,\%202016.html

Eom, T.K., Senevirathne, M. \& Kim, S.K. (2012). Synthesis of phenolic acid conjugated chitooligosaccharides and evaluation of their antioxidant activity. Environmental toxicology and pharmacology, 34, 519-527. https://doi.org/10.1016/i.etap.2012.05.004

Falcone, P., Speranza, B., Del Nobile, M.A., Corbo, M.R. \& Sinigaglia, M. (2005). A Study on the Antimicrobial Activity of Thymol Intended as a Natura Preservative. Journal of Food Protection, 68(8), 1664-1670. https://doi.org/10.4315/0362-028X-68.8.1664

Fekih, N., Allali, H., Merghache, S., Chaïb, F., Merghache, D., El Amine, M., Djabou, N., Muselli, A., Tabti, B. \& Costa, J. (2014). Chemical composition and antibacterial activity of Pinus halepensis Miller growing in West Northern of Algeria. Asian Pacific Journal of Tropical Disease, 4(2), 97-103. https://doi.org/10.1016/S2222-1808(14)60323-6

Finney, D.J. (1971). Probit analysis. 3rd Edition, Cambridge Univ. Press, Cambridge, $333 \mathrm{pp}$

García-Pérez, M.E., Royerb, M., Duque-Fernandez, A., Diouf, P.N., Stevanovic, T. \& Pouliot, R. (2010). Antioxidant, toxicological and antiproliferative properties of Canadian polyphenolic extracts on normal and psoriatic keratinocytes. Journal of Ethnopharmacology, 132, 251-258. doi: 10.1016/j.jep.2010.08.030

Ghanmi, M., Satrani, B., Chaouch. A., Aafi, A., El Abid, A., Ismaili, M.R. \& Farah A. (2007). Composition chimique et activité antimicrobienne de l'essence de térébenthine du pin maritime (Pinus pinaster) et du pin d'Alep (Pinus halepensis) du Maroc. Acta Botanica Gallica: Botany Letters, 154(2), 293-300. (Frensh) doi:http://dx.doi.org/10.1080/12538078.2007.10516058

Grether-Beck, S., Marini, A., Jaenicke, T., \& Krutmann, J. (2016) French Maritime Pine Bark Extract (Pycnogel $\left.{ }^{\circledR}\right)$ Effects on Human skin: Clinical and Molecular Evidence. Skin Pharmacology and Physiology. 29, 13-17. https://doi.org/10.1159/000441039

Gülçin, I., Elmastat, M. \& Aboul-Enein, H.Y. (2007). Determination of Antioxidant and Radical Scavenging Activity of Basil (Ocimumbasilicum $L$ Family Lamiaceae) assayed by different methodologies. Phytotherapy Research, 21, 354-361. https://doi.org/10.1002/ptr.2069

Guo, N., Liu, J., Wu, X., Bi, X., Meng, R., Wang, X., Xiang, H., Deng, X. \& Yu, L. (2009). Antifungal activity of thymol against clinical isolates of fluconazolesensitive and -resistant Candida albicans. Journal of Medical Microbiology, 58, 1074-1079. doi 10.1099/jmm.0.008052-0 0

Haichour, R., Ramdani, M., Lograda, T., Chalard, P. \& Figueredo, G. (2020). Chemical composition and antimicrobial activity of Pinus halepensis from Algeria. BIODIVERSITAS, 21(9), 4345-4360.

https://smujo.id/biodiv/article/view/6519

Hammadi, K., Selselet, A.G. \& Bensoltane, S.A. (2007). Dermatophytes in North West of Algeria a Prospective Study. Middle-East Journal of Scientific Research, 2 (3-4), 104-106. http://www.idosi.org/mejsr/mejsr2(3-4)/3.pdf

Ignat, I., Volf, I. \& Popa, V.I. (2011). A critical review of methods for characterisation of polyphenolic compounds in fruits and vegetables. Food Chemistry, 126, 1821-1835. https://doi.org/10.1016/j.foodchem.2010.12.026

Ilham, A. \& Touabti, A (2013). Les onychomycoses au laboratoire de parasitologie CHU Sétif: étude sur dix ans. Journal de Mycologie Médicale, 23(1), 81-82. https://doi.org/10.1016/j.mycmed.2012.12.036

Kaouachi, A. \& Derouiche, S. (2018). Phytochemical analysis, DPPH antioxidan activity and acute toxicity of bark aqueous extracts of Pinus halepensis. Research Journal of Chemical and Environmental Sciences, 6 (3), 86-91. http://www.aelsindia.com/ricesjune2018/14.pdf

Karepova, Z.A., Repyak, S.M. \& Levdikova, V.L. (1983). Acids of an aqueous extract of the woody verdure of the pine Pinus sylvestris. Chemistry of Natural Compounds, 19(3), 362-363. https://doi.org/10.1007/BF00579780

Kouamé, J., Gnoula, C., Palé, E., Bassolé, H., Guissou, I.P., Simporé, J. \& Nikiéma, J.B. (2009). Etude des propriétés cytotoxiques et anti-radicalaire d'extraits de feuilles et de galles de Guiera senegalensis J. F. Gmel (Combretacae). Science et technique, Sciences de la santé, 32(s 1 et 2), 9-23. https://www.ajol.info/index.php/stss/issue/archive
Krishnaiah, D., Sarbatly, R. \& Nithyanandam, R. (2011). A review of the antioxidant potential of medicinal plant species. Food and Bioproducts Processing, 89, 217-233. https://doi.org/10.1016/j.fbp.2010.04.008

$\mathrm{Ku}$, C.S., Jang, J.P. \& Mun, S.P. (2007). Exploitation of polyphenol-rich pine barks for potent antioxidant activity. Journal of Wood Science, 53, 524-528. do https://doi.org/10.1007/s10086-007-0896-6

Kumar, P. (2009). Green healers: A Review. In P. C. Trivedi (dir.), Medicinal Plants, Utilisation and Conservation. $\left(2^{\text {nd }}\right.$ Revised and Enlarged Edition, Aavishkar Publishers, Distributors, pp. 95-103). Jaipur 302003 (Raj) India.

Malik, C.P., Garg, P., Singh, Y. \& Grover, S. (2012). Medicinal uses, chemical constituents and micro propagation of three potential medicinal plants. International Journal of Life science and Pharma Research, 2(3), 57-76. https://www.ijlpr.com/archive-issue.php?issueid=4

Mansouri, N., Satrani, B., Ghanmi, M., El Ghadraoui, L., Guedira, A. \& Aafi, A (2011). Composition chimique, activité antimicrobienne et antioxydante de l'huile essentielle de Juniperus communis du Maroc. Bulletin de la Société Royale des Sciences de Liège, 80, 791 - 805. https://popups.uliege.be:443/00379565/index.php?id=3340

Meddour R. \& Meddour-Sahar O. (2015). Medicinal plants and their traditional uses in Kabylia (Tizi Ouzou, Algeria). Arabian Journal of Medicinal and
Aromatic
Plants,
$1(2)$

$137-151$.

Attps://revues.imist.ma/index.php/AJMAP/article/view/4331

Meziti, H., Bouriche, H., Kada, S., Demirtas, I., Kizil, M. \& Senator, A. (2019). Phytochemical analysis, and antioxidant, anti-hemolytic and genoprotective effects of Quercus ilex. and Pinus halepensis Mill. methanolic extracts. Journal of Pharmacy \& Pharmacognosy Research, 7 (4), 260-272. https://jppres.com/jppres/quercus-ilex-and-pinus-halepensis-biological-effects/

Miara, M.D., Bendif, H., Rebbas, K., Rabah, B., Hammou, M.A. \& Maggi, F. (2019). Medicinal plants and their traditional uses in the highland region of Bordj Bou Arreridj (Northeast Algeria). Journal of Herbal Medicine, 16, 100262 https://doi.org/10.1016/j.hermed.2019.100262

Nahal, I. (1962). Le pin d'Alep (Pinus halepensis Mill.). (1962). Etude taxonomique, phytogéographique, écologique et sylvicole. Annales de l'école nationale des eaux et forêts et de la station de recherches et expériences. Publication trimestrielle, tome XIX - fascicule 4-48 trimestre 1962. Nancy, Ecole Nationale Des Eaux Et Forêts.

Neacsu, M., Eklund, P.C., Sjöholm, R.E., Pietarinen, S.P., Ahotupa, M.O., Holmbom, B.R., \& Willför, S.M. (2007). Antioxidant flavonoids from knotwood of Jack pine and European aspen. Holz als Roh- und Werkstoff, 65, 1-6. doi: https://doi.org/10.1007/s00107-006-0121-0

Que, F., Mao, L. \& Pan, X. (2006). Antioxidant activities of five Chines rice wines and the involvement of phenolic compounds. Food Research International, 39, 581-587. https://doi.org/10.1016/j.foodres.2005.12.001

Rautio, M., Sipponen, A., Lohi, J., Lounatmaa, K., Koukila-Kähkölä, P. \& Laitinen, K. (2012). In vitro fungistatic effects of natural coniferous resin from Norway spruce (Piceaabies). European Journal of Clinical Microbiology and Infectious Diseases, 31, 1783-1789. https://doi.org/10.1007/s10096-011-1502-9

Rebbas K., Bounar R., Gharzouli R., Ramdani M., Djellouli Y. \& Alatou, D. (2012). Plantes d'intérêt médicinal et écologique dans la région d'Ouanougha (M'sila, Algérie). Phytothérapie 10(2), 131-142. https://pascalfrancis.inist.fr/vibad/index.php?action=getRecordDetail\&idt=25900129

Sarri, M., Sarri, D., Hendel, N., \& Boudjelal, A. (2012). Ethnobotanical study of therapeutic plants used to treat arterial hypertension in the Hodna region of Algeria. Global Journal of Research on Medicinal Plants \& Indigenous Medicine 1(9), $411-417$ https://www.researchgate.net/publication/283904425_Ethnobotanical_study_of_t herapeutic_plants_used_to_treat_arterial_hypertension_in_the_Hodna_region_of

\section{Algeria}

Sarri, M., Boudjelal, A., Hendel, N., Sarri, D. \& Benkhaled, A. (2015). Flora and ethnobotany of medicinal plants in the southeast of the capital of Hodna (Algeria). Arabian Journal of Medicinal \& Aromatic Plants, 1(1), 24-30. https://revues.imist.ma/index.php/AJMAP/article/view/3255/2349

Schmourlo, G., Mendonc, R.R., Filho, A., Alviano, C.S. \& Costa, S.S. (2005) Screening of antifungal agents using ethanol precipitation and bioautography of medicinal and food plants. Journal of Ethnopharmacology, 96, 563-568. https://doi.org/10.1016/j.jep.2004.10.007

Senouci, F., Ababou, A., Chouieb, M. \& Chouieb, M. (2019). Ethnobotanical Survey of the Medicinal Plants used in the Southern Mediterranean. Case Study: The Region of Bissa (Northeastern Dahra Mountains, Algeria). Pharmacognosy Journal, 11, 647-659. https://doi:10.5530/pj.2019.11.103

Shams Ghahfarokhi, M., Goodarzi, M., Razzaghi Abyaneh, M., Al-Tiraihi, T. \& Seyedipour G. (2004) Morphological evidences for onion-induced growth inhibition of Trichophyton rubrum and Trichophyton mentagrophytes. Fitoterapia, 75, 645- 655. doi: 10.1016/j.fitote.2004.06.009

Simard, F. (2007). Évaluation du potentiel anticancéreux des extractibles du bois de pin rouge. Maîtrise en ressources renouvelables, Université du Quebec.

Simpson, T., Kure, C., \& Stough, C. (2019). Assessing the Efficacy and Mechanisms of Pycnogenol ${ }^{\circledR}$ on Cognitive Aging From In Vitro Animal and Human Studies. Frontiers in Pharmacology, 10, 694. doi:https://doi.org/10.3389/fphar.2019.00694 
Sipponen, A. (2013). Coniferous resin salve, ancient and effective treatment for chronic wounds - Doctoral dissertation (article-based), Helsinki University Hospital, University of Helsinki, Helsinki, Finland.

Soltani, E., Cerezuela, R., Charef, N., Mezaache-Aichour, S., Angeles Esteban,

M. \& Zerroug, M.M. (2017). Algerian propolis extracts: Chemical composition, bactericidal activity and in vitro effects on gilthead seabream innate immune responses. Fish \& Shellf Immunology, 62, 57-67. http://dx.doi.org/10.1016/j.fsi.2017.01.009

Sun, T., \& Ho, C.T. (2005). Antioxidant activities of buckwheat extracts. Food Chemistry, 90, 743-749. https://doi.org/10.1016/j.foodchem.2004.04.035

Trapp, S., \& Croteau, R. (2001). Defensive resin biosynthesis in conifers. Annual Review of Plant Biology, 52, 689-724. doi: 10.1146/annurev.arplant.52.1.689

Walia, A., Gupta, A.K. \& Sharma, V. (2019). Role of Bioactive Compounds in Human Health". Acta Scientific Medical Sciences 3(9), 25-33. https://www.actascientific.com/ASMS-3-9.php\#popup1

Wojdyło, A, Oszmiański, J, \& Czemerys R. (2007). Antioxidant activity and phenolic compounds in 32 selected herbs. Food Chemistry, 105, 940-949. doi: http://dx.doi.org/10.1016/j.foodchem.2007.04.038 